\title{
RENAL FUNCTION IN PATIENTS WITH ADDISON'S DISEASE AND IN PATIENTS WITH ADRENAL INSUFFICIENCY SEC- ONDARY TO PITUITARY PAN-HYPOFUNCTION ${ }^{1}$
}

\author{
By JOHN H. TALBOTT, LOUIS J. PECORA, ROBERT S. MELVILLE, \\ AND WILLIAM V. CONSOLAZIO \\ (From the Medical Clinic, Massachusetts General Hospital and the Fatigue Laboratory, \\ Harvard University, Boston)
}

(Received for publication September 29, 1941)

Acute adrenal insufficiency is a complex phenomenon and at least three dysfunctions of body economy may accompany its development in humans. The disturbances which are intimately associated with the pathogenesis of adrenal insufficiency in patients suffering from Addison's disease are: $(a)$ dissipation of water and sodium with retention of potassium, (b) impaired glycogenesis from protein, and $(c)$ depression of renal activity. The existence of these disorders has been assumed from the clinical findings of hyponatremia and hyperproteinemia, hypoglycemia, and azotemia, respectively. Experimental studies concerning the precise dependence or the interdependence of these disturbances are not yet conclusive. Whether or not the several dysfunctions are interdependent, they are partially susceptible to investigation, independently. Thus it is possible to correct temporarily the disturbance of electrolyte exchange, meanwhile exerting little influence upon impaired glyconeogenesis. A clinical example of such an independence (1) is seen in patients with Addison's disease who die in hypoglycemic shock with a normal concentration of serum sodium.

Experimental studies recently performed suggest that impairment of renal function also may be independent of alteration of glyconeogenesis as well as independent of the typical disturbances of electrolyte equilibrium. The hypothesis has been tested in humans by quantitative measurements of the various functions of the kidney at different levels of adrenal activity. The results will be presented in this communication.

\footnotetext{
1 This investigation was aided by the Corn Industries Research Foundation. The authors wish to thank Dr. George W. Thorn of Baltimore and the Ciba Pharmaceutical Products Company for the generous quantities of desoxycorticosterone acetate (Percorten) supplied in oil and in pellets.
}

There are few studies reported in the literature which are pertinent to the discussion. The first reports were published in 1914 when three observers, independently, discussed the development of renal insufficiency in association with acute adrenal cortical insufficiency. Sicard and Haguenau (2) dismissed the matter with the statement that kidney insufficiency may be observed in humans during an adrenal crisis. Gaillard (3) made the first quantitative measurements of renal insufficiency and noted a blood urea of $320 \mathrm{mgm}$. per $100 \mathrm{cc}$. in a patient who had died from adrenal failure. A similar increase of waste products in the blood was noted by Porak and Chabanier (4) in animals following bilateral adrenalectomy. In 1916 Marshall and Davis (5) observed a delayed excretion of phenolsulphonphthalein dye as well as nitrogen retention in the adrenalectomized dog. They ascribed the changes to a "functional depression of the kidneys caused by a failure of elaboration by the adrenals of a substance necessary for maintenance of normal kidney function." Renal function in chronic adrenal insufficiency was measured by Stahl, Atchley and Loeb (6) in an adrenalectomized dog which was maintained for 9 months with adrenal cortical extract and salt without evidence of a progressive decrease in phenolsulphonphthalein excretion or urea clearance. A diminution in renal function was demonstrated only during an adrenal crisis which could be induced by withdrawal of either salt or extract. It is possible that if the dog had suffered from insidious chronic adrenal insufficiency for as long a time as do many patients with Addison's disease, evidence of renal damage might have been evident at other times than during an adrenal crisis.

Investigation of renal function during intercritical periods in a series of patients with Addison's disease was pursued first by Rowntree (7) who reported a decreased excretion of phenolsulphonphthalein dye 2 hours after injection in ten out of twelve patients. It is regrettable that fractional collection of urine samples was not practiced since the amount of dye excreted during a 2-hour collection period is not as accurate an index of mild renal insufficiency as is the per cent excreted in the first 15 minutes after injection. Subsequently, Rowntree and Snell (8) noted a decreased excretion of dye in acute adrenal insufficiency as well as hyposthenuria, albuminuria and cylinduria in patients with Addison's disease whose symptoms were controlled. Inability to concentrate urine was observed by Rosenow (9) in two patients with 
Addison's disease. He concluded that ability to concentrate urine was a function of the endocrine glands.

It is agreed that albuminuria, cylinduria and hyposthenuria are indicative of grave insults to the kidney. Less devastating alterations might occur, but would escape recognition because accurate measurements of small variations from the normal are not possible with the phenolsulphonphthalein and urine concentration tests. On the other hand, dependable quantitative methods for determination of renal efficiency by measuring rate of clearance of creatinine, inulin, diodrast and glucose have been developed only recently and have not been applied generally to patients with Addison's disease. Particularly pertinent is the application of these tests during the intercritical periods when symptoms are adequately or almost completely controlled as the result of administration of sodium chloride and hormones.

The creatinine clearance test devised by Rehberg (10) which measures, in humans, tubular excretory function as well as rate of glomerular filtration was applied by Margitay-Becht and Gömöri (11) to three patients with Addison's disease. Values of 68,63 , and $56 \mathrm{cc}$. of plasma cleared per minute, respectively, were observed during crises. Following parenteral administration of adrenal cortical extract, the rates increased to 105,109 , and 144 . All of these values are below normal except the last. It is stated that the depression in creatinine clearance showed no direct correlation with alteration of blood pressure, serum nonprotein nitrogen, serum sodium or colloid osmotic pressure of the serum. It is thought that these are the first data which show incomplete restoration of impaired tubular function and glomerular filtration in patients with Addison's disease whose symptoms are controlled by administration of adrenal cortical extract. McCance (12) reported an isolated datum of $50 \mathrm{cc}$. of glomerular filtrate formed per minute during an inulin clearance test in one patient with Addison's disease. No statement was made regarding symptoms, but the patient presumably was not in a severe crisis since he concluded that while hypotension, dehydration, diminution in plasma volume, hyperproteinemia, and uncompensated alkalosis might contribute to the pathogenesis of renal dysfunction in acute renal insufficiency, these factors would not explain the diminution in kidney efficiency observed. Finally, Gersh and Grollman (13) investigated glomerular filtration and tubular reabsorption of ferrocyanide salts in the rabbit, the dog, and the cat. These functions were studied immediately after adrenalectomy in some animals and 3 months post-operatively in others. No diminution in glomerular filtration was noted except late in an adrenal crisis. An increase in the rate of reabsorption of water by the tubules was apparent during severe adrenal insufficiency.

\section{SUBJECTS}

There are two clinical conditions with which may be associated a profound depression of adrenal cortical activity and which are sufficiently chronic in course to permit an accurate appraisal of changes in renal function. These are Addison's disease and pituitary hypofunction of the type designated as pan-hypopituitarism by Fraser, Albright and Smith (14). In this study ten patients with typical Addison's disease and six patients with chronic adrenal insufficiency secondary to pituitary hypofunction were investigated. Six persons acted as normal controls. None of the experimental subjects gave a history of having had acute or chronic nephritis. One patient, D. S., was suspected in 1935 of having renal tuberculosis. The diagnosis was not confirmed at that time or subsequently. A second patient, E. D., has had a persistent hypertension during the 2 years that he has been under observation. Otherwise no gross kidney disturbance was present in any subject.

The clinical methods for studying renal function were (a) determination of concentration of nonprotein nitrogen of the serum, $(b)$ testing ability to concentrate solids following abstinence from fluids for 12 hours, (c) urinary excretion of phenolsulphonphthalein dye 15 minutes after 1.0 cc. had been given intravenously, and $(d)$ pyelography after intravenous administration of $20 \mathrm{cc}$. of diodrast. More precise measurements of kidney function were obtained from estimation of rate of clearance of inulin, creatinine, diodrast, glucose, sodium, and potassium.

The theoretical considerations which underlie the various clearance procedures will not be discussed. We have assumed $(15,16)$ that inulin clearance measures rate of glomerular filtration, that creatine clearance measures rate of glomerular filtration plus tubular excretion, that diodrast clearance at low iodine plasma levels measures maximum renal plasma flow, that diodrast clearance at high iodine plasma levels measures maximum tubular capacity for excreting diodrast, and that glucose clearance at high plasma levels measures maximum tubular capacity for reabsorbing glucose.

The patients with Addison's disease (Table I) who were studied presented the typical clinical picture. They were chosen without regard to duration of symptoms. None was known to be suffering from any serious complication of Addison's disease or from an associated malady at the time that the tests were performed. Except for W. H., the excretion of 17 -ketosteroids was less than 10 


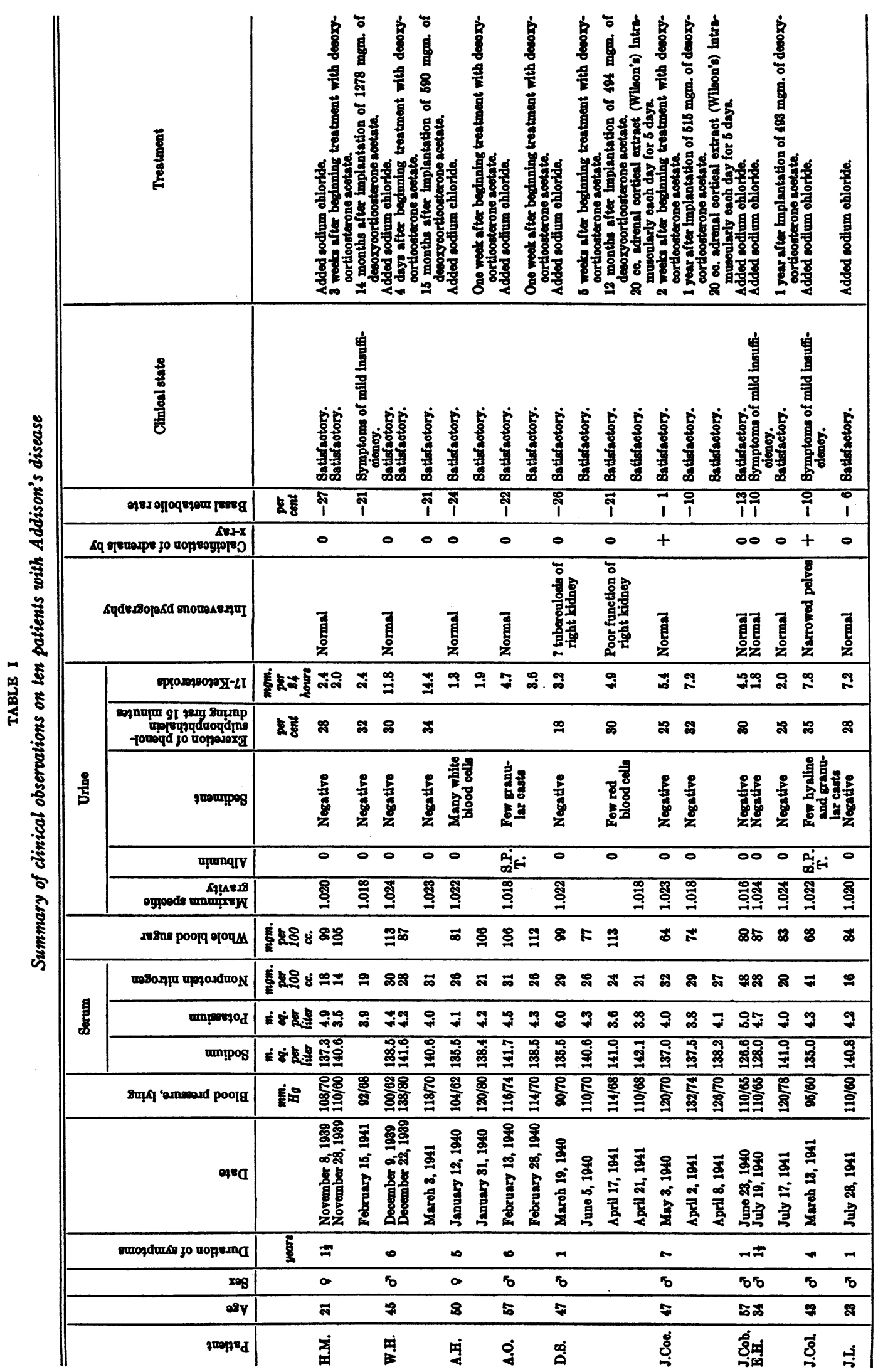


mgm. per 24 hours. The normal range for excretion of this fraction, as determined by our laboratory, is from 15 to $25 \mathrm{mgm}$. per 24 hours for adult males, and from 10 to $20 \mathrm{mgm}$. per 24 hours for adult females. The low values presented in Table $I$ are indicative of a severe depletion of adrenal cortical tissue. The basal metabolic rate was approximately 20 per cent below normal. Calcification of the adrenals was evident by $x$-ray in two patients. All of the patients except J. Coc. were studied first while they were on a high sodium chloride intake, but before receiving treatment with desoxycorticosterone acetate (Percorten). The first test on J. Coc. was performed 2 weeks after treatment with active material had begun. The tests were repeated on five patients from 2 to 6 weeks after institution of desoxycorticosterone acetate therapy. The requirements for desoxycorticosterone acetate were determined by the assay method described by Thorn and Firor (17). The active material was given first in oil over a period of 2 or more weeks. When the maintenance dose had been determined, pellets of desoxycorticosterone acetate were implanted. Five patients were re-investigated approximately a year later at the time that they were admitted for reimplantation of pellets. After this long interval of time they were beginning to note the effects of an inadequate assimilation of 'desoxycorticosterone acetate, but none was suffering from acute adrenal insufficiency. Two patients, whose electrolyte exchange had been restored by treatment with desoxycorticosterone acetate were studied before and after experimental administration of adrenal cortical extract (Wilson's). Twenty cc. of the extract were given daily intramuscularly in divided doses for 5 days.

Three Addison's patients have died since the data were collected. A. H. died from adenocarcinoma of the ovary with metastases. A postmortem examination showed caseous adrenals as well as carcinoma. A second patient, J. Cob., was a bartender and renegade. $\mathrm{He}$ was most uncooperative, and according to friends, died at home after an alcoholic bout. No autopsy was performed. A third patient, H. M., died suddenly in April 1941. Two months previously she had been admitted to the hospital for a new supply of desoxycorticosterone acetate pellets. This admission was uneventful. One month before death she was observed to be in good physical condition, her serum electrolytes were normal and the blood pressure was $128 / 82$. She lived only 18 hours after the sudden onset of weakness and hyperpyrexia. On the last admission, the serum sodium concentration was 126 m.eq. per liter; nevertheless, subcutaneous edema was obvious. The concentration of blood sugar was $88 \mathrm{mgm}$. per $100 \mathrm{cc}$. A continuous slow infusion of dextrose solution was given during the 18 hours preceding death. No autopsy was performed. The other patients with Addison's disease are alive and in a satisfactory state of compensation.

The patients suffering from pan-hypopituitarism (Table II) had symptoms of myxedema and chronic adrenal insufficiency. By pan-hypopituitarism we mean a type of Simmond's disease in which the most conspicuous feature is hypothyroidism (18) rather than cachexia. All of the patients with this malady were moderately incapacitated in contrast to those with Addison's disease. Each patient was admitted to the hospital because of distressing symptoms and all had metabolic rates below minus 20 per cent. Previous to admission four patients had had at least one crisis, the symptoms of which had been attributed to myxedema, but in retrospect are believed to have been those of adrenal insufficiency. All were ambulatory without requiring specific treatment at the time the renal function tests were done.

A diagnosis of chronic adrenal insufficiency in these patients was based upon the following evidence: $(a)$ the syndrome of pan-hypopituitarism is known to be associated with atrophy of the adrenals; (b) excretion of 17-ketosteroids in the urine was similar to patients with Addison's disease; (c) symptomatic improvement followed a high sodium chloride intake; $(d)$ only small amounts of thyroid extract were tolerated. The blood pressure was normal in all except E. D. This patient was the only one who showed evidence of renal damage by routine clinical tests. Four of the patients are alive and their symptoms are moderately well controlled on a high salt diet supplemented by parenteral administration of male or female sex hormones. Patient C. O. died from diabetes mellitus and hemochromatosis, symptoms of which appeared after renal function studies had been performed. Patient E. B. died following surgical removal of a suprasellar cyst. Atrophy 
TABLE II

Summary of clinical observations on six patients with pan-hypopituitarism

\begin{tabular}{|c|c|c|c|c|c|c|c|c|c|c|c|c|c|c|c|c|}
\hline \multirow[b]{2}{*}{ 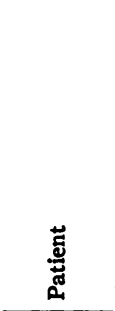 } & \multirow[b]{2}{*}{$\underset{4}{4}$} & \multirow[b]{2}{*}{ 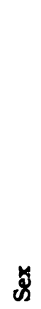 } & \multirow[b]{2}{*}{ 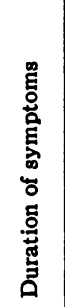 } & \multirow[b]{2}{*}{ జٌ } & \multirow[b]{2}{*}{ 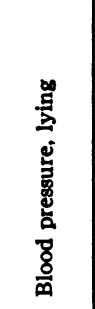 } & \multicolumn{3}{|c|}{ Serum } & \multirow[b]{2}{*}{ 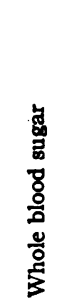 } & \multicolumn{5}{|c|}{ Urine } & \multirow[b]{2}{*}{ 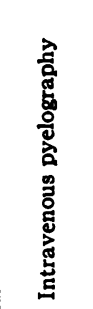 } & \multirow[b]{2}{*}{ 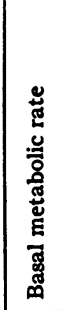 } \\
\hline & & & & & & E⿱ : & E & 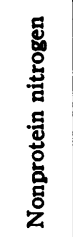 & & 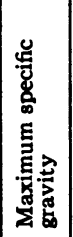 & 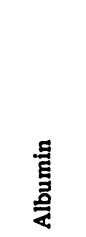 & 苞 & 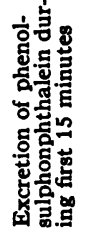 & 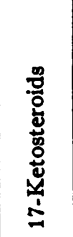 & & \\
\hline $\begin{array}{l}\text { N.W..... } \\
\text { C.O...... }\end{array}$ & $\begin{array}{l}54 \\
53\end{array}$ & $\begin{array}{l}\sigma \\
\sigma\end{array}$ & $\begin{array}{r}\text { years } \\
10 \\
2\end{array}$ & $\begin{array}{l}\text { November } 13,1939 \\
\text { December 15, } 1939 \\
\text { December 20, } 1939\end{array}$ & $\begin{array}{c}\mathrm{mm}_{\mathrm{H}} \\
\\
110 / 60 \\
100 / 65 \\
122 / 88\end{array}$ & $\begin{array}{l}m . \\
e q . \\
\text { per } \\
\text { liter } \\
138.7\end{array}$ & $\begin{array}{l}m . \\
e q . \\
\text { per } \\
\text { liter } \\
4.1\end{array}$ & $\begin{array}{c}\text { mgm. } \\
\text { per } \\
100 \\
c c . \\
20 \\
21\end{array}$ & $\begin{array}{c}\text { mgm. } \\
\text { per } \\
100 \\
c c . \\
96 \\
80 \\
286\end{array}$ & $\begin{array}{l}1.020 \\
1.022\end{array}$ & $\begin{array}{l}\mathbf{0} \\
\mathbf{0}\end{array}$ & Negative & $\begin{array}{l}\text { per } \\
\text { cent }\end{array}$ & $\begin{array}{c}\text { mgm. } \\
\text { per } \\
24 \\
\text { hours } \\
0.0 \\
2.0\end{array}$ & & $\begin{array}{l}\text { per } \\
\text { cent } \\
\\
-40 \\
-40 \\
-39\end{array}$ \\
\hline $\begin{array}{l}\text { D.A..... } \\
\text { E.D..... } \\
\text { E.B..... } \\
\text { B.L.... }\end{array}$ & $\begin{array}{l}29 \\
70 \\
27 \\
18\end{array}$ & $\begin{array}{l}q \\
\sigma \\
\sigma^{7} \\
\sigma^{\prime}\end{array}$ & $\begin{array}{r}5 \\
13 \\
1 \\
1\end{array}$ & $\begin{array}{l}\text { January } 30,1940 \\
\text { May 11, 1940 } \\
\text { November 25, 1940 } \\
\text { July 19, 1941 } \\
\text { August 4, 1941 }\end{array}$ & $\begin{array}{l}100 / 70 \\
170 / 85 \\
190 / 120 \\
110 / 70 \\
104 / 72\end{array}$ & $\begin{array}{l}138.5 \\
132.3 \\
138.4 \\
140.5\end{array}$ & $\begin{array}{l}4.3 \\
4.0 \\
4.4\end{array}$ & $\begin{array}{l}30 \\
29 \\
20 \\
18\end{array}$ & $\begin{array}{r}111 \\
74 \\
80 \\
82 \\
56\end{array}$ & $\begin{array}{l}1.022 \\
1.025 \\
1.012 \\
1.017 \\
1.022\end{array}$ & $\begin{array}{l}\mathbf{0} \\
\mathbf{0} \\
\text { S.P.T. } \\
\mathbf{0} \\
\mathbf{0}\end{array}$ & $\begin{array}{l}\text { Negative } \\
\text { Negative } \\
\text { Rare cast } \\
\text { Negative } \\
\text { Negative }\end{array}$ & $\begin{array}{l}13 \\
12 \\
34 \\
28\end{array}$ & $\begin{array}{l}2.4 \\
3.0 \\
3.3 \\
1.8 \\
3.2\end{array}$ & $\begin{array}{l}\text { Normal } \\
\text { Normal } \\
\text { Normal } \\
\text { Normal }\end{array}$ & $\begin{array}{l}-23 \\
-19 \\
-34 \\
-26 \\
-35\end{array}$ \\
\hline
\end{tabular}

of the adrenals was apparent at postmortem examination in both patients.

Although the term adrenal insufficiency is used frequently throughout this communication, none of the observations was made during an adrenal crisis. The study was planned in order to gather renal function data on ambulatory patients whose clinical symptoms were satisfactorily controlled. When the words adrenal insufficiency are used, therefore, it implies nothing more than an anatomical deficiency of adrenal cortical tissue. By this definition all patients with typical Addison's disease or pan-hypopituitarism, irrespective of apparent adequacy of treatment, are suffering from adrenal insufficiency. This statement is not intended to imply that the current drugs used in the treatment of Addison's disease are unsatisfactory. On the contrary, they have altered the clinical course of Addison's disease tremendously. Nevertheless, we believe that in most patients even this treatment does not provide for complete restoration.

During the period that these studies were in progress, seven additional patients with Addison's disease were admitted to the hospital in an acute adrenal crisis. Not one of these patients was thought to be a suitable subject for clearance tests since we were interested in renal function in chronic adrenal insufficiency. Microscopic examination of the kidneys from three of these patients is discussed under Pathological Observations.

\section{METHODS}

Most of the data were collected while the patients were in the research ward of the Massachusetts General Hospital. Approximately 25 grams of inulin were given intravenously for the determination of inulin clearance. For the determination of renal blood flow, the concentration of diodrast iodine in the serum was maintained at approximately $1 \mathrm{mgm}$. per $100 \mathrm{cc}$. Maximum tubular excretory capacity was determined with diodrast iodine levels in the serum, decreasing each 10-minute period from approximately $50 \mathrm{mgm}$. per $100 \mathrm{cc}$. to $25 \mathrm{mgm}$. per 100 cc. Maximum tubular reabsorption capacity was determined with rising serum glucose levels above 400 mgm. per $100 \mathrm{cc}$. The inulin, creatinine, sodium and potassium clearance and diodrast clearance at low plasma levels represent an average of 3 or more 10-minute collection periods. The data for diodrast and glucose clearance at high plasma levels are the average for 3 periods or less. All of the clearance tests are corrected to a body surface area of 1.73 sq.m. (16).

The tests were begun while the subjects were in a basal state except as regards consumption of water. One liter of fluid was allowed 12 hours and 2 hours, respectively, before each test. All urine specimens were collected by a urethral catheter. A sample of blood was taken at the halfway time in most periods. When this was not done, the concentration of constituents of serum was interpolated from data collected during periods immediately before and after. Venous blood was taken for all determinations except glucose. When concentration of this constituent was desired, arterial blood was taken from the brachial artery. Timing was done by means of a stop watch. Iodine was determined according to the method described by Smith and associates (16). The methods used for determination of the other constituents in blood and urine have been described (19). 
RESULTS

\section{Addison's disease}

In the summary given in Table I of the clinical observations on patients with Addison's disease, it is apparent that at the time most of the tests were performed, clinical evidence of acute adrenal insufficiency was lacking. At the time of the third test on H. M., at the time of the first test on E. H., and at the single test on J. Cob., symptoms of mild adrenal insufficiency were evident. The serum sodium concentrations during these tests tended to be less than 135 m.eq. per liter. In all determinations except the first on D. S., the serum potassium was within the range for normals. Laboratory and clinical evidence of hypoglycemia was absent in each patient. Previous to our studies, treatment in all patients except J. Coc. consisted only of a high salt intake and other conservative measures.

Examination of kidney function by routine clinical procedures showed no striking or constant variation from the normal. A total of 91 separate determinations, which include maximum specific gravity, phenolsulphonphthalein excretion, concentration of nonprotein nitrogen in the serum, albumin in the urine, urinary sediment and intravenous pyelography, are reported in Table I. Of these only 16 , or less than 18 per cent, were outside the average range for normals. Albumin was noted at $\mathbf{2}$ examinations, blood cells or casts at 4 examinations. Eight of the ten patients were able to concentrate urine to 1.020 during at least one examination. The nonprotein nitrogen was above $35 \mathrm{mgm}$. per $100 \mathrm{cc}$. in only two instances. The intravenous pyelogram was normal in all except two patients. All except one subject was able to excrete more than 25 per cent phenolsulphonphthalein dye during the first 15 minutes after injection.

In contrast to these data, the rate of formation of glomerular filtrate as determined by inulin clearance was below normal at the first observation in each patient (Table III). Thus, W. H. on December 9, 1939, had an inulin clearance of only $82 \mathrm{cc}$. per minute; yet he was able to concentrate urine to 1.024 and excreted 30 per cent of phenolsulphonphthalein dye during the first 15 minutes after intravenous injection. The values in nine patients ranged between $56 \mathrm{cc}$. and $97 \mathrm{cc}$. The average was $77 \mathrm{cc}$. In our investigations of inulin clearance we have chosen arbitrarily $100 \mathrm{cc}$. of plasma per minute as the lower limit for a normal person and $120 \mathrm{cc}$. as an average normal value. These data are similar to those reported by Goldring and associates (20).

Following the first series of renal function studies, desoxycorticosterone acetate in oil was administered and, later, pellets of this substance were implanted. Subsequently, an increase in rate of formation of glomerular filtrate was apparent in the five patients on whom this function was studied. The increases averaged 32 per cent, a significant gain. Simultaneous clinical improvement was more subtle than obvious since the patients were in a relatively satisfactory clinical condition at the time of the initial tests. Following implantation of pellets for one year or longer, the improvement in renal function noted shortly after institution of desoxycorticosterone acetate therapy had regressed in all except E. H. Three of the five patients on whom these tests were repeated showed an inulin clearance below that observed at the time of the first admission to the hospital. This result is not surprising since the life of the pellets used in this study is approximately 12 months and the amount of drug available from this source decreases rapidly after one year. It should be stressed, however, that except for H. M. no clinical symptoms of acute adrenal insufficiency were apparent and the patients were readmitted because we had advised it. Each patient believed that clinical improvement which developed month by month following desoxycorticosterone acetate therapy had been maintained in a large part.

The effect of administration of adrenal cortical extract (Wilson's) upon kidney function was investigated in two patients. Each was given $20 \mathrm{cc}$. of the material daily in divided doses intramuscularly for 5 days. The extract was given to ascertain whether it would have any demonstrable effect upon inulin clearance. No striking improvement in clinical state was anticipated because this was satisfactory before administration of this material. The experiment was negative in both subjects. It was concluded that adrenal cortical extract in the doses given is unable to restore impaired renal function in patients with Addison's 
disease beyond that achieved by desoxycorticosterone acetate.

Creatinine clearance was determined simultaneously with inulin clearance in most instances. A normal person excretes approximately 25 per cent of the total creatinine by means of tubular excretory activity and the remainder by glomerular filtration. The patients with Addison's disease in our series excreted slightly more than 30 per cent of the total by the tubules and proportionately less by glomerular activity. This is indirect evidence that glomerular filtration in Addison's disease is depressed to a greater extent than is renal blood flow; the latter supplying creatinine-containing blood for tubular excretion.

Further evidence to support the assumption that in Addison's disease glomerular filtration suffers more than does renal blood flow was deduced from measurements of diodrast clearance at low plasma levels (Table III). Effective renal blood flow may be calculated from diodrast clearance at low plasma levels and cell volume. This function was not determined in many patients, but the collected observations show proportionately less depression below normal than do inulin clearances. Renal plasma flow averaged $465 \mathrm{cc}$. per minute in 10 tests on the Addisonian patients. The average for the normal subjects was $690 \mathrm{cc}$. per minute. Administration of adrenal cortical extract did not affect this function.

The ratio of glomerular filtration to renal plasma flow has been designated filtration fraction by Smith. In five normal subjects this averaged 21.5 per cent. In the Addison's patients it averaged 15.7 per cent. A diminution in filtration fraction may be accomplished by a decrease in blood pressure or a diminution of tone of efferent arterioles of the nephron. Since the blood pres-

TABLE III

Renal function observations on ten patients with Addison's disease

\begin{tabular}{|c|c|c|c|c|c|c|c|c|c|c|c|c|}
\hline \multirow{2}{*}{ Patient } & \multirow{2}{*}{ Date } & \multirow{2}{*}{$\begin{array}{c}\text { Body } \\
\text { surface }\end{array}$} & \multirow{2}{*}{$\begin{array}{l}\text { Aver- } \\
\text { age } \\
\text { urine } \\
\text { flow } \\
\text { during } \\
\text { test }\end{array}$} & \multicolumn{5}{|c|}{$\begin{array}{l}\text { Cc. of plasma cleared per minute. } \\
\text { Average of } 3 \text { or more periods. }\end{array}$} & \multirow{2}{*}{$\begin{array}{l}\text { Effec- } \\
\text { tive } \\
\text { renal } \\
\text { blood } \\
\text { flow }\end{array}$} & \multirow{2}{*}{$\begin{array}{l}\text { Dio- } \\
\text { drast- } \\
\text { iodine } \\
\text { Tm. }\end{array}$} & \multirow{2}{*}{$\begin{array}{l}\text { Glu- } \\
\text { cose } \\
\text { Tm. }\end{array}$} & \multirow{2}{*}{$\begin{array}{l}\text { Filtra- } \\
\text { tion } \\
\text { frac- } \\
\text { tion }\end{array}$} \\
\hline & & & & Inulin & $\begin{array}{c}\text { Creati- } \\
\text { nine }\end{array}$ & $\begin{array}{l}\text { Sodi- } \\
\text { um }\end{array}$ & $\begin{array}{l}\text { Potas- } \\
\text { sium }\end{array}$ & $\begin{array}{l}\text { Dio- } \\
\text { drast- } \\
\text { iodine }\end{array}$ & & & & \\
\hline H.M. & $\begin{array}{l}\text { November 8, } 1939 \\
\text { November 28, } 1939 \\
\text { February } 15,1941\end{array}$ & $\begin{array}{l}\text { sq. } m . \\
1.40 \\
1.41 \\
1.34\end{array}$ & \begin{tabular}{|c|}
$c c$. \\
per \\
minute \\
6.6 \\
7.3 \\
0.6
\end{tabular} & $\begin{array}{r}97 \\
102 \\
55\end{array}$ & $\begin{array}{l}152 \\
145\end{array}$ & $\begin{array}{l}6.8 \\
6.5 \\
0.9\end{array}$ & $\begin{array}{l}27.2 \\
35.3\end{array}$ & 442 & $\begin{array}{c}c c . \\
\text { per } \\
\text { minute }\end{array}$ & 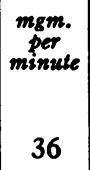 & $\underset{\substack{\text { per } \\
\text { minute }}}{\operatorname{mgm} .}$ & $\begin{array}{l}\begin{array}{c}\text { per } \\
\text { cent }\end{array} \\
12.5\end{array}$ \\
\hline W.H. & $\begin{array}{l}\text { December 9, } 1939 \\
\text { December 23, } 1939 \\
\text { March 3, } 1941\end{array}$ & $\begin{array}{l}1.63 \\
1.64 \\
1.68\end{array}$ & $\begin{array}{r}5.7 \\
11.5 \\
3.9\end{array}$ & $\begin{array}{r}82 \\
100 \\
57\end{array}$ & $\begin{array}{l}118 \\
159\end{array}$ & $\begin{array}{l}0.9 \\
2.9 \\
0.7\end{array}$ & $\begin{array}{r}8.9 \\
10.1 \\
7.8\end{array}$ & 592 & 924 & 42 & & 9.7 \\
\hline A.H. & $\begin{array}{l}\text { January } 12,1940 \\
\text { January } 31,1940\end{array}$ & $\begin{array}{l}1.42 \\
1.44\end{array}$ & $\begin{array}{l}1.9 \\
2.5\end{array}$ & $\begin{array}{r}70 \\
106\end{array}$ & $\begin{array}{l}122 \\
125\end{array}$ & $\begin{array}{l}1.7 \\
4.0\end{array}$ & $\begin{array}{r}9.4 \\
12.8\end{array}$ & & & & & \\
\hline A.O. & $\begin{array}{l}\text { February 13, } 1940 \\
\text { February } 28,1940\end{array}$ & $\begin{array}{l}1.48 \\
1.52\end{array}$ & $\begin{array}{l}1.3 \\
1.1\end{array}$ & $\begin{array}{l}82 \\
91\end{array}$ & $\begin{array}{l}115 \\
139\end{array}$ & $\begin{array}{l}0.6 \\
1.4\end{array}$ & $\begin{array}{l}7.7 \\
9.2\end{array}$ & & & & & \\
\hline D.S. & $\begin{array}{l}\text { March 19, } 1940 \\
\text { June 5, 1940 } \\
\text { April 17, } 1941 \\
\text { April 21, } 1941\end{array}$ & $\begin{array}{l}1.42 \\
1.46 \\
1.49 \\
1.49\end{array}$ & $\begin{array}{l}4.0 \\
2.0 \\
2.8 \\
1.8\end{array}$ & $\begin{array}{l}56 \\
95 \\
78 \\
72\end{array}$ & $\begin{array}{r}69 \\
132\end{array}$ & $\begin{array}{l}2.8 \\
0.5\end{array}$ & $\begin{array}{r}6.7 \\
14.4\end{array}$ & $\begin{array}{l}358 \\
376\end{array}$ & $\begin{array}{l}560 \\
586\end{array}$ & & $\begin{array}{l}186 \\
188\end{array}$ & $\begin{array}{l}21.8 \\
19.2\end{array}$ \\
\hline J.Coc. & $\begin{array}{l}\text { May 3, } 1940 \\
\text { April 4, 1941 } \\
\text { April 9, } 1941\end{array}$ & $\begin{array}{l}1.65 \\
1.67 \\
1.68\end{array}$ & $\begin{array}{l}1.5 \\
2.7 \\
3.2\end{array}$ & $\begin{array}{l}92 \\
70 \\
68\end{array}$ & 132 & $\begin{array}{l}1.1 \\
0.3 \\
0.9\end{array}$ & 7.8 & $\begin{array}{l}416 \\
366\end{array}$ & $\begin{array}{l}614 \\
538\end{array}$ & 23 & & $\begin{array}{l}16.8 \\
18.9\end{array}$ \\
\hline J.Cob. & June 23,1940 & 1.61 & 2.4 & 82 & 103 & 1.8 & 10.8 & & & & & \\
\hline E.H. & $\begin{array}{l}\text { July } 19,1940 \\
\text { July } 17,1941\end{array}$ & $\begin{array}{l}1.85 \\
1.84\end{array}$ & $\begin{array}{l}3.1 \\
1.0\end{array}$ & $\begin{array}{l}68 \\
80\end{array}$ & 116 & $\begin{array}{l}1.2 \\
1.0\end{array}$ & $\begin{array}{r}12.1 \\
6.0\end{array}$ & $\begin{array}{l}388 \\
504\end{array}$ & $\begin{array}{l}682 \\
840\end{array}$ & $\begin{array}{l}29 \\
36\end{array}$ & 153 & $\begin{array}{l}17.5 \\
15.9\end{array}$ \\
\hline J.Col. & March 13, 1941 & 1.86 & 1.0 & 81 & & 0.5 & & 690 & 1110 & & , & 11.8 \\
\hline J.L. & July 28, 1941 & 1.64 & 1.8 & 74 & & & 2.6 & 520 & 850 & 35. & $\cdot$ & 14.2 \\
\hline
\end{tabular}


sures were essentially normal, it is assumed that the decreased fraction was produced by efferent arteriolar relaxation.

The observations on maximum tubular capacity for excretion of diodrast (diodrast $T m$.) and maximum tubular capacity for reabsorption of glucose (glucose $T \mathrm{~m}$.) are too few for one to draw conclusions. It may be stated, however, that tubular excretory capacity appears to be maintained remarkably well, while capacity for reabsorbing glucose is impaired seriously. Reabsorption of water by the tubules was calculated for five patients before and after treatment with desoxycorticosterone acetate. The percentile reabsorption was unchanged in three patients, increased in one and decreased in one. No significant change was noted in the two patients who received adrenal cortical extract. Our data, therefore, do not confirm the conclusions of Gersh and Grollman (13) and Silvette and Britton (21) that tubular reabsorption of water is increased in animals in adrenal insufficiency. Increased tubular reabsorption of water would be a rather unexpected finding since glomerular filtration is depressed. Furthermore, in acute adrenal insufficiency increased urinary output accompanies development of symptoms.

The exchange of sodium, chloride and potassium by the kidney was calculated as cc. of plasma cleared per minute and recalculated to determine per cent reabsorption by the tubules according to

the formula $\left(1-\frac{\text { sodium clearance }}{\text { inulin clearance }}\right) \times 100$. In employing the term clearance for electrolyte exchange, we have assumed that it implies and embodies a process similar to the clearance of substances such as urea, phosphate, and urate. Inherent aspects of electrolyte clearance include appearance of these substances in the glomerular filtrate in the same concentration as they exist in plasma, and reabsorption in part by tubular cells as the glomerular filtrate passes through the tubular lumina. We have assumed that electrolytes are not excreted by the tubules.

The electrolyte clearances were determined because the statement has been made that the tubule cannot absorb adequate quantities of sodium in adrenal insufficiency $(22,23)$. Additional data on this subject seemed desirable. Normal persons on a sodium chloride intake of from 6 to 10 grams per day will have a "sodium clearance" of from 1 to $5 \mathrm{cc}$. of plasma per minute. All of the Addison's patients except $H$. M. had a sodium clearance within this range or below. During the period of the test, therefore, no dissipation of sodium was apparent. Similar conclusions were reached by Schäfer (24) who employed a different technique for the study of renal activity of the adrenalectomized dog and cat. Our conclusions are not intended to imply that a dissipation of sodium does not occur in adrenal insufficiency (25). In fact these clearance data may be interpreted as confirming the assumption that, during the tests, none of the patients was suffering from acute adrenal insufficiency. An alternate explanation for our inability to detect any dissipation of sodium is that these studies on renal function are not sufficiently precise to detect subtle variations in sodium exchange. The results obtained from the calculation of tubular reabsorption of chloride are scattered and are not conclusive.

The data on potassium clearance appear to be more definitive. Each of the first five patients studied showed an increased clearance of potassium following treatment with desoxycorticosterone acetate. This was an expected result since this substance promotes elimination of potassium as well as retention of sodium. The increased excretion of potassium is produced mainly by an increase in glomerular filtration. Calculation of the amount reabsorbed by substituting potassium clearance in the above-mentioned formula gives scattered results just as for sodium.

\section{Adrenal insufficiency secondary to pan-hypopituitarism}

All of the patients with pituitary hypofunction showed a profound depression in inulin clearance (Table IV). The average for the group was approximately one-half that for normal controls. Creatinine clearance showed a smaller percentile decrease from normal, as was observed in patients with Addison's disease. More than 30 per cent of the creatinine excreted was by means of tubular activity. Diodrast clearance at low plasma levels was determined on two patients. The filtration fractions were 21.1 and 19.1 per cent, respectively. 
TABLE IV

Renal function observations on six patients with pan-hypopituitarism

\begin{tabular}{|c|c|c|c|c|c|c|c|c|c|c|}
\hline \multirow[b]{2}{*}{ 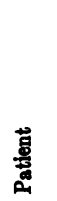 } & \multirow[b]{2}{*}{ 量 } & \multirow{2}{*}{ 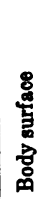 } & \multirow{2}{*}{ 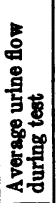 } & \multicolumn{5}{|c|}{$\begin{array}{l}\text { Cc. of plasms oleared per } \\
\text { minute. Average of } 3 \text { or } \\
\text { more periods. }\end{array}$} & \multirow{2}{*}{ 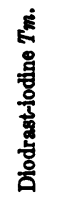 } & \multirow{2}{*}{ 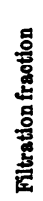 } \\
\hline & & & & 量 & 蚂: & 罡 & 蚂 & 要。 & & \\
\hline & & m. & $\underset{\substack{c c \\
\text { min- } \\
\text { ute }}}{\mid}$ & & & & & & $\begin{array}{c}\text { mom. } \\
\text { per } \\
\text { min- } \\
\text { uts }\end{array}$ & $\begin{array}{l}\text { per } \\
\text { cent }\end{array}$ \\
\hline N.W. & $\begin{array}{l}\text { November } 13,1939 \\
\text { December } 15,1939\end{array}$ & $\begin{array}{l}1.35 \\
1.37\end{array}$ & $\begin{array}{l}0.9 \\
1.8\end{array}$ & $\begin{array}{l}49 \\
40\end{array}$ & 70 & $\begin{array}{l}0.3 \\
0.6\end{array}$ & $\begin{array}{r}16.9 \\
9.0\end{array}$ & & & \\
\hline c.o. & December 20, 1839 & 1.71 & 9.6 & 70 & 118 & 1.0 & 8.5 & & & \\
\hline D.A. & January 30; 1940 & 1.87 & 8.0 & 61 & 89 & 0.6 & 21.3 & & & \\
\hline E.D. & $\begin{array}{l}\text { May 11, } 1940 \\
\text { November 25, } 1940\end{array}$ & $\begin{array}{l}1.70 \\
1.81\end{array}$ & $\begin{array}{r}11.4 \\
7.6\end{array}$ & $\begin{array}{l}63 \\
43\end{array}$ & 81 & $\begin{array}{l}7.4 \\
5.2\end{array}$ & $\begin{array}{l}11.8 \\
13.3\end{array}$ & 204 & 16.6 & 21.1 \\
\hline E.B. & July 19, 1941 & 1.64 & 5.1 & 61 & & & & 320 & 27.5 & 19.1 \\
\hline B.L. & August 4, 1941 & 1.64 & 9.8 & 77 & & & & & 43.9 & \\
\hline
\end{tabular}

\section{Normal controls}

The effect of desoxycorticosterone acetate upon renal activity was studied in two normal subjects, B. C. and B. D. Each subject was given daily $10 \mathrm{mgm}$. of the substance in oil for 7 days. Clearance studies before and after administration to B. C. were similar. Before-administration studies were not done on B. D. but after-treatment studies were within the average range for normals.
These observations suggest that desoxycorticosterone acetate does not influence rate of formation of glomerular filtrate in normal persons. Several observations of sodium and potassium clearance were made on $R$. J. following a high as well as a low potassium intake (Table V). High potassium clearances followed a high potassium intake. They approximated inulin clearance, which indicates that most of the potassium which appeared in the glomerular filtrate was excreted and was not reabsorbed. On a low potassium intake, the clearance of potassium was maintained within the average range for normals. Large changes in potassium clearance were not reflected by a similar change in sodium clearance. It is suggested that sodium and potassium possess independent mechanisms for excretion by the kidney and no reciprocal excretion of these substances is manifest.

\section{PATHOLOGICAL OBSERVATIONS}

One of our interests in pursuing this investigation of renal function in adrenal insufficiency was the reported absence of structural damage in the kidney of patients dying from Addison's disease $(2,26,27,28,29)$. One might assume, therefore, that the changes in the kidney were "functional" and reversible if the adrenal insufficiency could be controlled. A comprehensive study of

TABLE $V$

Renal function observations on six control subjects

\begin{tabular}{|c|c|c|c|c|c|c|c|c|c|c|c|c|c|}
\hline \multirow{2}{*}{ 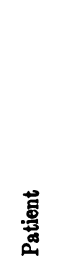 } & \multirow[b]{2}{*}{$\stackrel{8}{4}$} & \multirow[b]{2}{*}{ \$ } & \multirow[b]{2}{*}{$\stackrel{\$}{\text { 苟 }}$} & \multirow{2}{*}{ 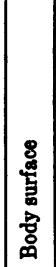 } & \multirow{2}{*}{ 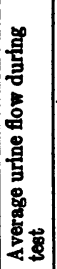 } & \multicolumn{5}{|c|}{$\begin{array}{l}\text { Co. of plasma cleared } \\
\text { per minute. A verage } \\
\text { of } 3 \text { or more periods }\end{array}$} & \multirow{2}{*}{ 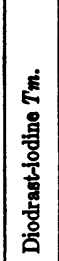 } & \multirow{2}{*}{ 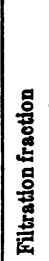 } & \multirow{2}{*}{ Remarks } \\
\hline & & & & & & 昜 & 胥 & 㞼 & $\frac{9}{8}$ & 売 & & & \\
\hline R.J. & $\begin{array}{c}\text { years } \\
40\end{array}$ & $\sigma^{7}$ & $\begin{array}{l}\text { January 4, } 1939 \\
\text { January 3,1940 } \\
\text { January } 6,1940 \\
\text { January 16, } 1940 \\
\text { January 19, } 1940\end{array}$ & $\begin{array}{l}\text { qq. } \\
\text { m. } \\
1.63 \\
1.68 \\
1.68 \\
1.67 \\
1.68\end{array}$ & $\begin{array}{c}c c . \\
\text { per } \\
\text { min- } \\
\text { ute } \\
\\
16.6 \\
17.2 \\
16.8 \\
7.5\end{array}$ & $\begin{array}{r}112 \\
103 \\
104 \\
95 \\
98\end{array}$ & $\begin{array}{l}153 \\
131 \\
145 \\
142 \\
142\end{array}$ & $\begin{array}{l}2.0 \\
5.4 \\
3.1 \\
3.2 \\
5.1\end{array}$ & \begin{tabular}{|l|}
25.4 \\
75.1 \\
78.4 \\
11.4 \\
12.3
\end{tabular} & & $\begin{array}{c}\operatorname{mom} . \\
\text { per } \\
\text { min- } \\
\text { ute }\end{array}$ & per & $\begin{array}{l}\text { Normal regimen. } \\
7 \text { grams of potassium chloride during } 3 \text { hours before test. } \\
\text { Low potassium diet for } 8 \text { days. } \\
\text { Low potasium diet for } 11 \text { days. } 30 \text { grams sodium chloride during } 48 \text { hours } \\
\text { before test. }\end{array}$ \\
\hline B.C. & 19 & ه & $\begin{array}{l}\text { November } 14,1940 \\
\text { December 10, } 1940\end{array}$ & $\begin{array}{l}1.74 \\
1.74\end{array}$ & $\begin{array}{l}8.5 \\
2.0\end{array}$ & $\begin{array}{l}183 \\
190\end{array}$ & $\begin{array}{l}254 \\
269\end{array}$ & $\begin{array}{l}4.9 \\
1.7\end{array}$ & $\begin{array}{l}16.1 \\
20.2\end{array} \mid$ & 730 & $\begin{array}{l}66.4 \\
65.4\end{array}$ & $\begin{array}{l}25.0 \\
26.7\end{array} \mid$ & $\begin{array}{l}\text { Normal regimen. } \\
10 \text { mgm. deanycorticosterone acetate intramuscularly each day for } 7 \text { days. }\end{array}$ \\
\hline D.D. & 54 & $\sigma^{\lambda}$ & November 22, 1940 & 1.99 & 8.4 & 116 & 164 & 3.4 & 8.8 & 530 & 43.8 & 21.9 & $10 \mathrm{mgm}$. desoxyeorticosterone acetate intramuscularly each for day 7 daye. \\
\hline L.C. & 32 & \& & December 4, 1940 & 1.64 & 8.8 & 122 & 179 & 2.8 & 27.4 & 676 & 54.5 & 18.1 & Normal regimen. \\
\hline R $\mathbf{8}$. & 18 & $\sigma^{7}$ & July 27, 1940 & 1.77 & 3.5 & 185 & 210 & 3.1 & & 870 & 44.0 & 21.3 & Normal regimen. \\
\hline F.M. & 23 & q & August 7, 1940 & 1.61 & 9.2 & 139 & 190 & 1.1 & & 675 & 48.0 & 20.6 & Normal regimen. \\
\hline
\end{tabular}


postmortem material was reported by Guttman (30) in 1929. In a statistical study of 566 autopsied cases of Addison's disease collected from the literature, less than 10 per cent showed morphologic changes in the kidneys sufficient to justify an anatomic diagnosis of renal disease. Approximately one-half of this number showed tuberculosis of the kidney; the remainder showed among other conditions acute and chronic nephritis and pyelonephritis.

Somewhat different findings were reported by Barker (31) in thirty-one autopsied cases. Ten of this number showed tubular atrophy which consisted of "flattening of the epithelial cells and diminution in the amount of cytoplasm. The tubular lumina usually appeared diminished in diameter with intertubular edema. Occasionally, fat was evident in the tubular cells." Barker interpreted these changes as the analogue of a toxic nephrosis which had been produced by hypotension and anoxemia. Similar pathological findings have been observed in adrenalectomized animals. Fat deposits in the epithelium of the collecting tubules have been noted in the cat $(5,32)$ and general swelling of the tubular cells in the dog (33). It is of interest that Simpson and Korenchevsky (34) prevented the development of degenerative changes in the tubules of rats following adrenalectomy by the use of adrenal cortical extract. No mention was made of time allowed for the development of degenerative changes or the amount of extract necessary for prevention of changes.

In our series of patients none of them gave a history of having had any renal disturbance and a diagnosis of acute or chronic nephritis, nephrosis, or pyelonephritis was not presumed in any. D. S. had changes by intravenous pyelogram which suggested unilateral tuberculosis of the kidney. He has been followed over a period of more than 4 years and the diagnosis has never been confirmed either by medical or urological consultants. Injection of a sample of urine into a guinea pig did not lead to tuberculosis in the animal.

Finally, we are able to report on postmortem material from three patients studied in this series as well as three other patients who died from Addison's disease. The microscopic examinations were made by Dr. B. M. Castleman. The kidneys of A. H. at autopsy showed minimal structural changes consistent with pyelitis and pyelonephritis. It is significant that our studies which were done 5 months before death from carcinoma showed a low normal inulin clearance following implantation of pellets. If the pyelonephritis were playing a large rôle in depression of glomerular filtration, it is assumed that desoxycorticosterone acetate could not have restored this function to normal. It is concluded that glomerular filtration on entry was not depressed because of pyelonephritis, but was an integral part of the adrenal disturbance. C. O. had normal kidneys except for small deposits of hemosiderin. It is not believed that the hemosiderin deposits had interfered seriously with renal function during life. The kidneys of E. B.; as well as those of three other patients who died from Addison's disease during the past 2 years, but who were not suitable patients for clearance studies, appeared normal.

\section{DISCUSSION}

The capacity of the kidney has been investigated in patients with Addison's disease and in patients with adrenal cortical atrophy secondary to pituitary hypofunction. Both groups of patients were studied at a time when clinical symptoms of acute adrenal insufficiency were absent. The data reported, therefore, are to be interpreted as an integral part of controlled adrenal insufficiency rather than severe adrenal depletion. Renal function was studied by the clinical tests usually applied and by more quantitative measurements of specific renal activity. Routine clinical tests in the majority of instances were normal. On the other hand, precise measurement of renal function by the clearance tests recently described by Smith and associates showed considerable impairment.

Rate of formation of glomerular filtrate as measured by inulin clearance was depressed significantly in all patients before treatment. From 1 to 4 weeks following treatment with desoxycorticosterone acetate, the patients with Addison's disease showed partial restoration of glomerular filtration. One year or more following implantation of pellets of desoxycorticosterone acetate and, in spite of continued clinical improvement, regression of glomerular filtration rate had taken place. Renal plasma flow as measured by diodrast 
clearance at low plasma levels showed a smaller percentile depression than did inulin clearance. The ratio of inulin clearance to diodrast clearance, i.e., filtration fraction, was considerably below normal. Of all the measured functions, maximum tubular capacity for excreting diodrast at high iodine plasma levels was affected least. Maximum tubular capacity for reabsorbing glucose at high plasma levels was most affected.

There are several factors which might be responsible for the pathogenesis of renal impairment in symptomatically controlled adrenal insufficiency. These are (1) vasomotor unresponsiveness and hypotension, (2) increase in concentration of serum protein, (3) decrease in metabolic rate, (4) structural changes in the kidney, (5) non-specific result of a chronic disease, and (6) lack of some specific action of one or more adrenal cortical hormones.

Diminution of blood pressure may be suspected because hypotension might produce many of the observed changes. In acute adrenal insufficiency, a significant depression in renal function undoubtedly may be attributed to hypotension. In our studies, however, blood pressures were normal in most instances. Furthermore, if hypotension had been responsible, renal plasma flow should have suffered quite as much as inulin clearance, instead of the reverse. The data suggest a diminution in efferent arteriolar tone with less impairment of tubular activity than rate of formation of glomerular filtrate. This is consistent with the clinical findings of a poorly functioning vasomotor system.

Dehydration with increase in colloid osmotic pressure was not seriously implicated because the concentrations of serum protein were within the range for normal.

A decrease in metabolic rate has not been entirely excluded as being responsible for the observed effects. In Addison's disease, as well as in adrenal insufficiency secondary to pituitary hypofunction, the metabolic rate is depressed. If the averages of the two groups are compared, the patients with pituitary hypofunction had a greater depression of kidney function as well as a greater depression in metabolic rate. Since the hormone produced by the thyroid has an effect upon cellular activity generally, it is reasonable to assume that depressed tubular activity may follow inadequate elaboration of it.

Structural changes in the kidney are observed infrequently in Addison's disease and cannot be held responsible for the functional impairment.

We cannot refute with certainty the supposition that the observed changes are the effect of a chronic disease per se. Signs of grave renal insufficiency which accompany acute adrenal insufficiency argue for a more specific relationship.

Maintenance of the integrity of the kidney by hormones of the adrenal cortex was postulated by Marshall and Davis in 1914 (5). Such a postulation is not unreasonable and partial restoration in inulin clearance immediately following treatment with desoxycorticosterone acetate supports it. The failure of kidney function to be maintained a year after implantation of pellets and the absence of improvement in renal function in Addison's disease following administration of adrenal cortical extract negate the postulation.

In conclusion, the correct explanation of the pathogenesis of renal impairment may be multiple rather than single. A combination of all or of most of the hypotheses would be in keeping with the statement made in the introduction of the paper, i.e., adrenal insufficiency is a complex phenomenon.

\section{SUM MARY}

Studies of kidney function have been pursued in ten patients with chronic adrenal insufficiency associated with Addison's disease and in six patients with chronic adrenal insufficiency associated with pan-hypopituitarism. All of the patients except two gave a negative history for acute or chronic renal disease. In most instances the patients were well compensated and symptoms of severe adrenal insufficiency were not present immediately before, during or after any of the tests. The function tests included accepted clinical procedures, as well as clearance of inulin, creatinine, diodrast, glucose, sodium, chloride and potassium.

The clinical tests for renal disease were normal in most patients. On the other hand, more precise tests showed evidence of impairment of all measured aspects of renal function in all patients at most examinations. Rate of formation of glomerular filtrate and tubular reabsorptive ca- 
pacity for glucose were affected most. Renal plasma flow was affected less and tubular capacity for excreting diodrast was affected least. The filtration fraction was depressed below normal. Administration of desoxycorticosterone acetate corrected partially, but temporarily, these deficiencies. Administration of adrenal cortical extract had no demonstrable action upon the measured functions. Administration of desoxycorticosterone acetate to two normal persons was without demonstrable effect upon renal activity.

The pathogenesis of these aberrations is assumed to be "functional" in so far as no structural changes are consistently observed in the kidneys of patients who have died from adrenal insufficiency. Vasomotor unresponsiveness, a decrease in metabolic rate, a nonspecific effect of a chronic disease, and a lack of specific action by the adrenal cortical hormones may each contribute.

\section{BIBLIOGRAPHY}

1. Loeb, R. F., Atchley, D. W., and Parson, W., The significance of certain chemical abnormalities found in the blood in Addison's disease. Tr. A. Am. Physicians, 1937, 52, 228.

2. Sicard, J. A., and Haguenau, Dosage de l'Ureé Sanguine des Addisoniens. Bull. et mem. Soc. med. d. Hôp. de Paris, 1914, 37, 902.

3. Gaillard, L., Insuffisance Surrénale et Azotémie. Bull. et mem. Soc. med. d. Hôp. de Paris, 1914, 37, 272.

4. Porak, R., and Chabanier, H., Altération de la Sécrétion Renale Aprés l'Albation des Glandes Surrénales. Compt. Rend. Soc. de Biol., 1914, 77, 440.

5. Marshall, E. K., Jr., and Davis, D. M., The influence of the adrenals on the kidneys. J. Pharmacol. and Exper. Therap., 1916, 8, 525.

6. Stahl, J., Atchley, D. W., and Loeb, R. F., Observations on adrenal insufficiency. J. Clin. Invest., 1936, 15, 41.

7. Rowntree, L. G., Studies in Addison's disease. J. A. M. A., 1925, 84, 327.

8. Rowntree, L. G., and Snell, A. M., A Clinical Study of Addison's Disease. W. B. Saunders Co., Philadelphia, 1931.

9. Rosenow, G., Ueber die Nierenfunktion bei der Addison'schen Krankheit. Med. Klin., 1925, 21, 202.

10. Rehberg, P. B., Studies on kidney function. II. The excretion of urea and chloride analyzed according to a modified filtration-reabsorption theory. Biochem. J., 1926, 20, 461.

11. Margitay-Becht, E., and Gömöri, P., Die Nierenfunktion bei der Addison'schen Krankheit. Ztschr. $f$. d. ges. exper. Med., 1938, 104, 22.
12. McCance, R. A., Medical problems in mineral metabolism. II. Sodium deficiencies in clinical medicine. Lancet, 1936, 1, 765.

13. Gersh, I., and Grollman, A., Kidney function in adrenal cortical insufficiency. Am. J. Physiol., 1939, 125, 66.

14. Fraser, R., Albright, F., and Smith, P. H., Carbohydrate metabolism. The value of the glucose tolerance, test, the insulin tolerance test, and the glucose-insulin tolerance test in the diagnosis of endocrinologic disorders of glucose metabolism. J. Clin. Endocrinology, 1941, 1, 297.

15. Shannon, J. A., and Smith, H. W., The excretion of inulin, xylose and urea by normal and phlorizinized man. J. Clin. Invest., 1935, 14, 393.

16. Smith, H. W., Goldring, W., and Chasis, H., The measurement of the tubular excretory mass, effective blood flow and filtration rate in the normal human kidney. J. Clin. Invest., 1938, 17, 263.

17. Thorn, G. W., and Firor, W. M., Desoxycorticosterone acetate therapy in Addison's disease. Clinical considerations. J. A. M. A., 1940, 114, 2517.

18. Means, J. H., Hertz, S., and Lerman, J., The pituitary type of myxedema or Simmonds' disease masquerading as myxedema. Tr. A. Am. Physicians, 1940, 55, 32.

19. Coombs, F. S., Pecora, L. J., Thorogood, E., Consolazio, W. V., and Talbott, J. H., Renal function in patients with gout. J. Clin. Invest., 1940, 19, 525.

20. Goldring, W., Chasis, H., Ranges, H. A., and Smith, H. W., Relations of effective renal blood flow and glomerular filtration to tubular excretory mass in normal man. J. Clin. Invest., 1940, 19, 738.

21. Silvette, H., and Britton, S. W., Renal function in normal and adrenalectomized opossums and effects of post-pituitary and cortico-adrenal extracts. Am. J. Physiol., 1938, 121, 528.

22. Darrow, D. C., Renal function in adrenal insufficiency. Connecticut State M. J., 1940, 4, 393.

23. Darrow, D. C., and Harrison, H. E., The chemical composition of tissues in adrenal insufficiency. $\mathrm{J}$. Biol. Chem., 1938, 123, xxvii.

24. Schäfer, W., Die Nierenfunktion nach Nebennierenextirpation. Ztschr. f. d. ges. exper. Med., 1933, 90, 552.

25. Harrison, H. E., and Darrow, D. C., Renal function in experimental adrenal insufficiency. Am. J. Physiol., 1939, 125, 631.

26. Stahl, J., Kuhlmann, D., and Urban, M., Les Troubles de la Sécrétion Uréique au cours de l'Insuffisance Surrénalienne. Compt. rend. Soc. de biol., 1928, 127, 1283.

27. Mainzer, F., Ueber die Störung der "Nierenfunktion" bei Addison'schen Krankheit. Schweiz. med. Wchnschr., 1937, 67, 31.

28. Joelson, J. J., and Shorr, E., The relation of the suprarenals to cholesterol metabolism. Arch. Int. Med., 1924, 34, 841. 
29. Mozer, J. J., De l'influence de la Surrénale sur le Fonctionnement du Rein. Presse med., 1929, 37, 156.

30. Guttman, P. H., Addison's disease. A statistical analysis of five hundred and sixty-six cases and a study of the pathology. Arch. Path., 1930, 10, 742.

31. Barker, N. W., The pathologic anatomy in twentyeight cases of Addison's disease. Arch. Path., $1929,8,432$.
32. Hartmann, F. A., MacArthur, C. G., Gunn, F. D., Hartman, W. E., and MacDonald, J. J., Kidney function in adrenal insufficiency. Am. J. Physiol., 1927, 81, 244.

33. Banting, F. G., and Gairns, S., Suprarenal insuffciency. Am. J. Physiol., 1926, 77, 100.

34. Simpson, S. L., and Korenchevsky, V., Histological changes in the kidneys of adrenalectomized rats. J. Path. and Bact., 1935, 40, 483. 